\title{
Expression of androgen, estrogen, and progesterone hormone receptors in the penile tissues of children with different types of hypospadias
}

\author{
(D) Aysenur Celayir, ${ }^{1}$ (D) Serdar Moralioglu, ${ }^{1}$ (1) Handan Cetiner, ${ }^{2}$ (D) Gozde Kir, ${ }^{3}$ (D) Sinan Celayir ${ }^{4}$ \\ ${ }^{1}$ Department of Pediatric Surgery, Health Science University Istanbul Zeynep Kamil Maternity and Children's Diseases Health Training and \\ Research Center, Istanbul, Turkey \\ 2Department of Pathology, Health Science University Istabnbul Zeynep Kamil Maternity and Children's Diseases Health Training and Research \\ Center, Istanbul, Turkey \\ ${ }^{3}$ Department of Pathology, Istanbul Medeniyet University Goztepe Training and Research Hospital, Istanbul, Turkey \\ ${ }^{4}$ Department of Pediatric Surgery, Istanbul University Cerrahpasa Faculty of Medicine, Istanbul, Turkey
}

\begin{abstract}
OBJECTIVE: Androgen (AR), Estrogen (ER) and Progesterone (PR) hormones play an important role in the prenatal and postnatal development of urogenital tract and especially the penis. The expressions of AR, ER and PR receptors in penile tissues in children with hypospadiases had also been shown previously. In this leading study, to demonstrate of the sex hormone receptor expression in cases with different types of hypospadias were aimed.

METHODS: This study was designed in children operated due to hypospadiases without DSD. Biopsy samples of 3 mm's were obtained from three different sytes as the lateral parameatal tissue and the anterior corner of the prepuce, and inner layer of posterior prepuce. The presence of AR, ER and PR receptors was investigated immunehistochemically.

RESULTS: Mean age was 5.4 years in 18 children with hypospadiases; in totally 33 specimens were taken in 5 subcoronal as 5 specimens, and 7 penile as 15 specimens, and 6 penoscrotal as 13 specimens. According to sytes of samples; 13 samples were from lateral para-meatal tissues, and 13 were from anterior corners of prepuces, and 7 were from inner layers of posterior prepuces. In regard to receptor expression; ER and AR receptors were positive in $29(87.8 \%)$ and $12(36.4 \%)$ respectively; PR receptors were negative.

CONCLUSION: This study emphasized the dominant expression of estrogen receptors in penile tissues of children with hypospadias. Although there was not a manifest correlation of androgen receptors absence in regard to the severity of hypospadias patients, there was a marked estrogen receptors presence in penile tissues. These findings suggest that the disrupted androgen and estrogen receptor interaction and/or balance could play a role during the development of external genitalia in hypospadias patients. Progesterone receptor was not present and therefore the active role in the postnatal development of hypospadias is still debatable.
\end{abstract}

Keywords: Androgen; estrogen; hormone; hypospadias; penis; progesterone; receptor.

Cite this article as: Celayir A, Moralioglu S, Cetiner H, Kir G, Celayir S. Expression of androgen, estrogen, and progesterone hormone receptors in the penile tissues of children with different types of hypospadias. North Clin Istanb 2019;6(2):110-116.

Received: October 26, 2017 Accepted: February 09, 2018 Online: September 24, 2018

Correspondence: Dr. Aysenur CELAYIR. Saglik Bilimleri Universitesi, Istanbul Zeynep Kamil Kadin ve Cocuk Hastaliklari Egitim ve Arastirma Hastanesi, Cocuk Cerrahisi Klinigi, Istanbul, Turkey.

Tel: +9053232656 69 e-mail: celayiraysenur@gmail.com

(c) Copyright 2019 by Istanbul Provincial Directorate of Health - Available online at www.northclinist.com

(c) (1) (1) This work is licensed under a Creative Commons Attribution-NonCommercial 4.0 International License. 
Tn humans, like in other mammals, the gonads, the internal genital ducts, and the external genital structures all develop from bi-potential embryologic tissues. Male or female phenotype develops through a cascade of processes that initiate with sex determination and follow with sex differentiation [1]. The karyotype of the embryo determines whether primordial gonad will differentiate into a testis or an ovary, respectively as known gonadal differentiation. It is the $\mathrm{Y}$ chromosome that is essential for the development of the male reproductive organs, and without no the $\mathrm{Y}$ chromosome, an embryo will develop into a female. In both males and females, the sex organs consist of three structures: the gonads, the internal genitalia, and the external genitalia $[1,2]$. However, a Y-related gene, the SRY gene on the Y chromosome triggers the development of male sex-related characteristics in the embryonic period, particularly the testis formations. The testis development process also involves several steps controlled by other non-OY-linked genes.

Over the 5 weeks, the fetus begins producing hormones that cause its sex organs to develop into either male or female organs. The differentiation of external male genitalia requires the transformation of testosterone to di-hydro-testosterone by 5-alpha reductase type 2 expressed in the genital skin and urogenital sinus [2]. The effects of androgens occur in the presence of the functional androgen receptor protein. Mutations of genes coding for steroidogenic enzymes, anti-Mullerian hormone, anti-Mullerian hormone receptor, androgen receptor and 5-alpha reductase are all associated with impairment of sex differentiation $[1,2]$.

Androgen, estrogen and progesterone effect and play an important role in the prenatal and postnatal development of the urogenital tract, especially the penis [3-8]. The effect and role of these sex hormone receptors on the pathogenesis of hypospadias were shown in previous studies, and the expressions of androgen, estrogen and progesterone receptors of the penile tissues in children with/without hypospadias were demonstrated [9-11]. In this leading study, an examination of the sex hormones receptors expression (AR, ER and $P R$ ) in different types of hypospadias was targeted.

\section{MATERIALS AND METHODS}

\section{Materials}

This study included patients operated due to hypospadias. They were investigated with regard to different

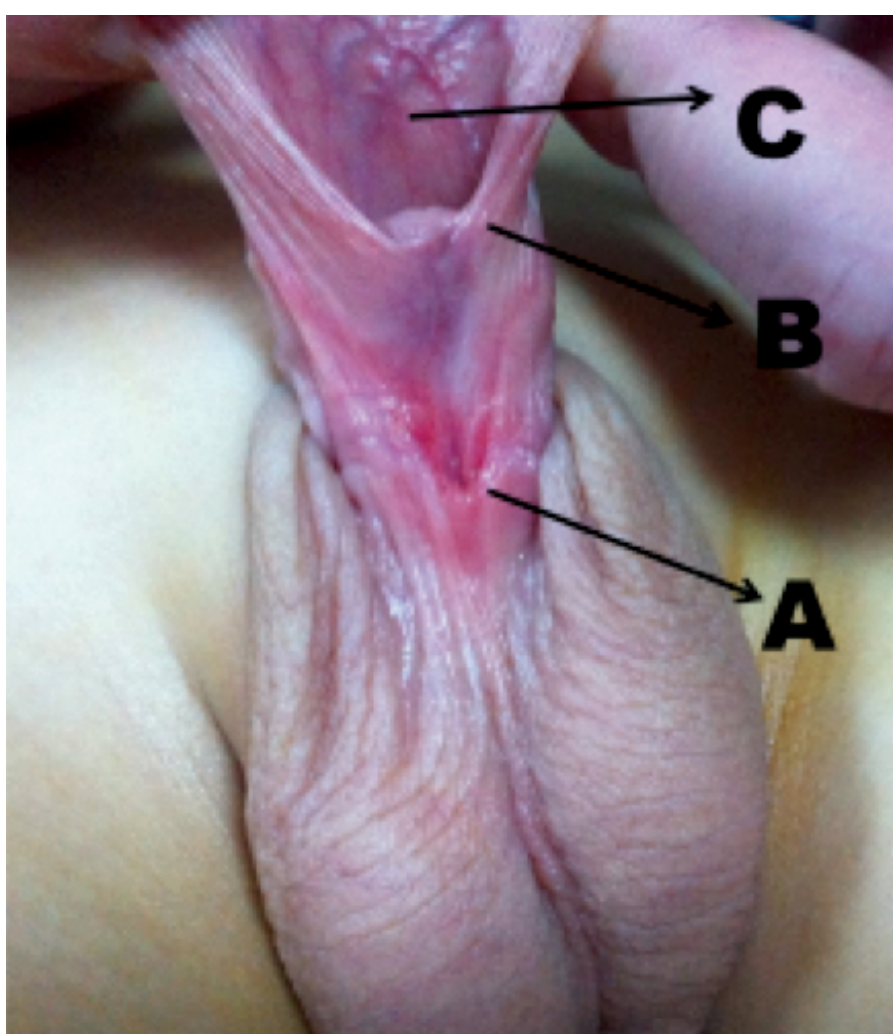

FIGURE 1. Biopsy specimens were taken from the excision materials in patients during the hypospadias surgery. The sites of the biopsy specimens were the lateral parameatal tissue next to the urethral sulcus, the corner of the anterior prepuce, and the inner surface of the posterior prepuce.

types of hypospadias (subcoronal, penile and penoscrotal) and the site of biopsy. All biopsy specimens were obtained from excision materials during the hypospadias surgery. The sites of the biopsy are a specimen from near the parameatal tissues next to the urethral sulcus (A), a specimen from the corner of the anterior prepuce (B), and a specimen from the inner surface of the posterior prepuce $(\mathrm{C})$; locations of the biopsy are shown in Figure 1. The existence and density of androgen, estrogen and progesterone hormone receptors were investigated. The ethical committee of our hospital approved this study (2012/18537), and the families gave their concent to investigate the biopsy specimens, which were taken during the hypospadias surgery from the excision materials.

\section{Surgical Technique}

All patients operated with a single-stage repair of hypospadias with circumcision. The onlay procedure was used in two patients with penoscrotal hypospadias; the others were operated with technique of the Tubularized 

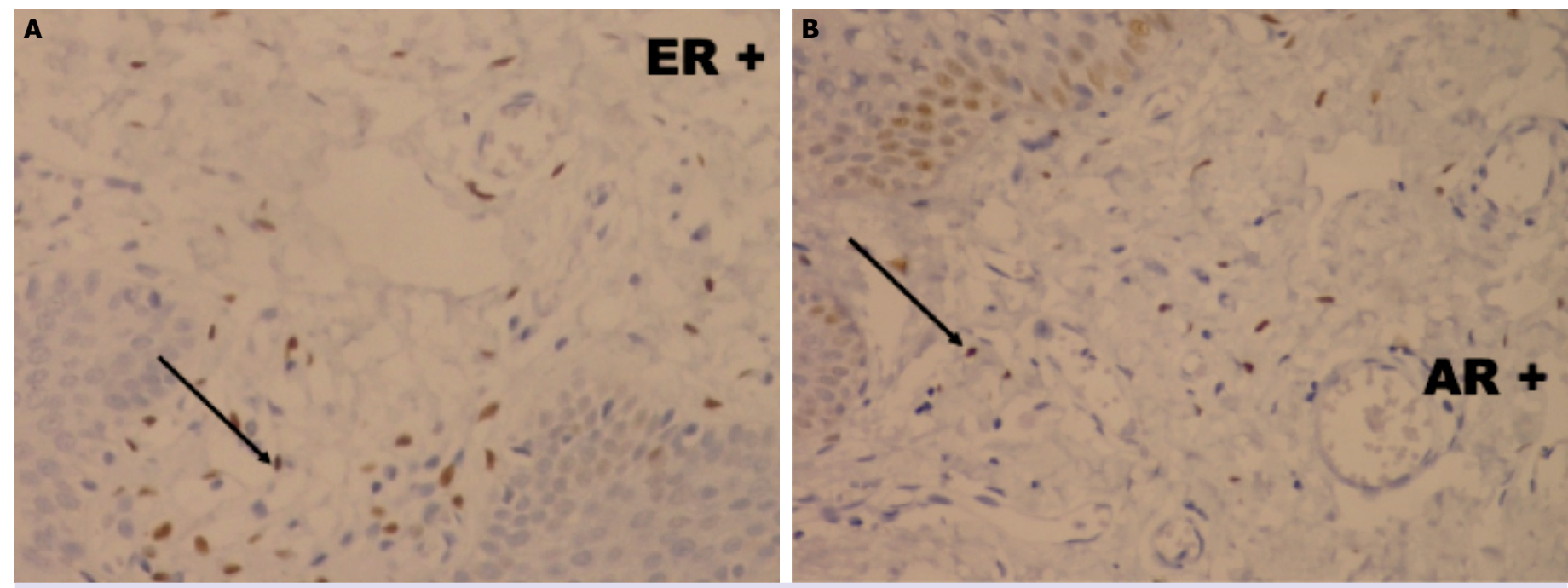

FIGURE2. Reactions were interpreted as positive based on nuclear staining as brown color for estrogen (in shown $\mathbf{A}$ ) and androgen (in shown B) receptors; reactions were interpreted as negative if there was not neclear staining like as progesteron receptors.

Incised Plate Uretroplasty (TIPU). During The Tubularized Incised Plate Urethroplasty or Onlay Urethroplasty, the edges of the urethral plate below the glandular level are usually very thin, devoid of the corpus spongiosum, and required a little trimming to perform the tubularization of the urethral plate, and these are the specimens from the urethral plate in same cases. A glandular tissue was removed during the closure of glans wings from the inside of the glans penis, and the prepuce was sampled after the circumcision. Samples from the corner of the anterior prepuce and the posterior inner layer of the prepuce were sampled in all patients.

\section{Immunohistochemistry}

An Avidin-Biotin Horseradish Peroxidase Technique was used to lokalize the expressions of Estrogen, Progesterone and Androgen in the different samples using ER receptor (SP1) (Dacopatts, Accurate NY, USA), PR receptor (SP2) (Dacopatts, Accurate NY, USA) and AR receptor (SP107) (Sigma, MO, USA) antibodies [12]. Briefly, the sections were dewaxed, dehydrated in alcohol and treated with $2 \%$ hydrogen peroxide for 20 minutes in methanol to block endogenous peroxide. The sections used were pre-trated in an 850-Watt domestic microwave oven in the $0.01 \mathrm{M}$ citrate buffer ( $\mathrm{pH}$ 6.0) for 5 minutes. The sections were incubated for 30 minutes with normal horse serum (Vector Laboratories, Burlingham, CA, USA) and then incubated with the primary antibodies over night at 4 Celsius. The following day the sections were washed with $20 \mathrm{mM}$ phosphate buffered saline $(\mathrm{pH}$
7.3 , saline concentration is $20 \%$ ) and then incubated with 1:200 biotinylated horse anti-mouse secondary antibody for 30 minutes. After a further wash step, all sections were incubated with the avidin-biotin peroxide complex ELITE system (Vector Laboratories, Inc., Burlingham, $\mathrm{Ca}$, USA) for 30 minutes and then subsequently with 3,3-diaminobenzidine (Vector Laboratories, Burlingham, CA,USA) for 10 minutes. Sections were washed in tap water, counter-stained with Gill's haematoxylin, dehydrated in a series of graded ethanol, cleared in xylene, and mounted.

All prepared sections were examined under the light microscope. Reactions were interpreted as positive based on nuclear staining with brown color and negative if there was not nuclear staining for Estrogen, Progesteron and Androgen receptors respectively (Fig. 2A, B).

\section{RESULTS}

This study compromised findings of eighteen patients with different grade of the hypospadias. Sixteen patients underwent the tubularized incised plate urethroplasty and 2 patients underwent onlay urethroplasty. The mean age was 5.39 years old (range $2-10$ years). There were no patient with a disorders of the sex development in this selected group, only one one patient had undescended testes.

A total of 33 biopsy specimens were taken from 18 patients. Five specimens were taken from 5 patients with subcoronal hypospadias, 15 from 7 with had penile hypospadias, and 13 from 6 patients with penoscrotal hy- 
TABLE1. Distribution of the receptor positivity in total specimens

\begin{tabular}{lcc} 
Receptor & Biopsy & $\%$ \\
\hline Estrogen & $28 / 33$ & 87.8 \\
Androgen & $12 / 33$ & 36.4 \\
Progesterone & $0 / 33$ & 0
\end{tabular}

pospadias. In 33 biopsy specimens, 13 specimens were from lateral parameatal tissues, 13 were from anterior prepuce, and 7 were from the inner layer of posterior prepuce. According to the results of the avidin-biotin Horseradish Peroxidase Immunohistochemical Technique Staining, estrogen receptors were found positive in 29 of 33 biopsy specimens (87.8\%). The AR receptors were found positive in 12 of 33 biopsy specimens (36.4\%). The PR receptors were found negative in all specimens. Results of the avidin-biotin horseradish peroxidase technique staining in all biopsy specimens were summarised in Table 1.

The hypospadias degree: In subcoronal hypospadias, the ER receptors were positive in 4 of 5 specimens (80\%), and the AR receptors were positive in 2 of 5 specimens (40\%). In penile hypospadias, the ER receptors were positive in 13 of 15 specimens (86.7\%), the AR receptors were positive in 5 of 15 specimens (33.3\%). In penoscrotal hypospadias the ER receptors were positive in 11 of $13(84.6 \%)$, the AR receptors were positive in 5 of 13 (38.5\%) respectively (Table 2 ).

The biopsy location: In lateral parameatal tissues, the ER receptors were positive in 9 of 13 specimens (69.2\%), the $\mathrm{AR}$ receptors were positive in 5 of 13 specimens (38.5\%). In biopsy specimens of the anterior prepuce, the ER receptors were positive in 13 of 13 specimens $(100 \%)$, the androgen receptors were positive in 4 of 13 specimens $(30.8 \%)$. In biopsy specimens of the posterior inner preputium, the ER receptors were positive in 7 of $7(100 \%)$ and the AR receptors were positive in 3 of 7 (42.8\%) respectively (Table 3 ).

\section{DISCUSSION}

Human male fetuses become externally distinct between 8 and 12 weeks, as androgens enlarge the phallus and cause the urogenital groove and sinus to fuse at the midline, producing an unambiguous penis with
TABLE 2. Receptor positivity according to type of hypospadias

\begin{tabular}{ccc} 
& & $\%$ \\
\hline $\begin{array}{c}\text { Subcoronal hypospadias } \\
\text { Estrogen receptor }\end{array}$ & $4 / 5$ & 80.0 \\
Androgen receptor & $2 / 5$ & 40.0 \\
Penile hypospadias & & \\
Estrogen Receptor & $13 / 15$ & 86.7 \\
Androgen receptor & $5 / 15$ & 33.3 \\
Penoscrotal hypospadias & & 84.6 \\
Estrogen receptor & $11 / 13$ & 38.5 \\
Androgen receptor & $5 / 13$ & \\
& &
\end{tabular}

TABLE 3. Receptor positivity according to the biopsy site. Sites of the biopsy specimens are A) 13 specimens from lateral parameatal tissue near the urethral sulcus, B) 13 specimens from the corner of the anterior prepuce, and C) 7 specimens from the inner surface of the posterior prepuce

$\%$

Parameatal tissue

Estrogen receptor

$9 / 13$

69.2

Androgen receptor

$5 / 13$

38.5

Anterior prepuce

Estrogen receptor

$13 / 13$

100

Androgen receptor

$4 / 13$

30.8

Posterior prepuce

Estrogen receptor

$7 / 7$

100

Androgen receptor

$3 / 7$

42.8

a phallic urethra, and a thinned, curled scrotum. The testes begin to secrete three hormones (anti-Mullerian hormone, testosterone, and di-hydro-testosterone) that influence the male internal and external genitalia. Anti-Mullerian hormone causes the regression of the paramesonephric ducts. Testosterone, which is secreted, converts the mesonephric ducts into male accessory structures, such as epididymis, vas deferens and seminal vesicle. Testosterone will also control the descending of the testes from the abdomen into the scrotum. The di-hydro-testosterone, will differentiate the remaining male characteristics of the external genitalia. A sufficient amount of AR can cause external masculinization. The most potent is di-hydro-testosterone, generated 
from testosterone in the skin and genital tissue by the action of $5 \alpha$-reductase [1-8].

Current theories on the mechanisms of sexual differentiation in humans are based primarily on three sources of evidence: Small numbers of outcomes with disorders of sexual development were demontrated in some animal researchs involving manipulation of hormones in early life [13-17]. In mammals, like in humans, the gonads, the internal genital ducts, and the external genital structures all develop from bi-potential embryologic tissues [13]. It is known that the effects of hormones were by receptors and their mediators. There are a lot of hormone-receptor studies about the sexual differentiation in mammals. Their results suggest that androgens may play an important role in the development of the male genitalia at a much earlier stage than indicated by previously published work and that the scrotal development in this species may not be AR-independent [14, 15]. Findings were discussed with respect to similarities and differences between marsupials and eutherians in hormonal environment during the perinatal period and with respect to the possible role of androgens in sexual differentiation of the gray opossum brain [16]. Advances in understanding frequently come from studying experimental findings from animal models. In review of the study by Hutson et al., the key issues that urologists need to understand in order to link animal studies to clinical practice were discussed; that review employed two common disorders: Hypospadias and undescended testes [13].

Androgens contribute to testicular descent and, differentiation of male external genitalia [1-4]. ER is known mainly as a female hormone effecting female sex differentiation. However, the demonstration of estrogen receptors in both sexes and especially in male tissues raised the questions about the role of female hormones in male urogenital system development. Cunha et al. also showed that estrogens played a critical role in the penile and clitoral development, specifying the position of the urethral orifice, determining elasticity of the urethral meatus, and facilitating epithelial- fusion events required for proper formation of the distal urethra/urogenital sinus and prepuce [17]. Accordingly, prenatal inhibition of estrogen synthesis via the administration of letrozole as an aromatase inhibitor leads to malformations of the glans as well as the prepuce or hypospadias. The effects of prenatal androgens, anti-androgens and impaired estrogen synthesis correlated with the tissue expression of androgen and estrogen receptors $[17,18]$. These data demonstrated that estrogen plays an active role in pre- natal penile development as androgen does. Up to date, the relevance of estrogen receptors in the development of urethra has not been clearly understood $[5-8,17$, $18]$. There is a hormonal balance between androgen and estrogen hormones during the development of external genitalia [1-5].

Hypospadias is a spectrum of diseases and the ultimate cause is probably a defect in the androgen stimulation of the developing penis. But the increased risk of hypospadias in the sons of women exposed to di-ethylstilbestrol and a higher incidence of hypospadias in the last decade have raised the questions about the effects of estrogen in the etiology of hypospadias $[10,11]$. The expression of estrogen and androgen receptors in human fetal penile tissue was previously demonstrated in some studies $[1-5,7,8,10,11,18,19]$. The estrogenic effects on target tissues are mediated mainly by two types of estrogen receptors; classical estrogen receptor alpha $(\mathrm{ER} \alpha)$ and estrogen receptor beta $(\operatorname{ER} \beta)[20,21]$.

The presence of AR and ER receptors in the bladder trigone of boys have been demonstrated previously by immunohistochemistry and the possible role/effects of AR and ER hormones in children with lower urinary tract dysfunction were implemented [9]. In a recent study, circumcision materials were biopsied from the intact prepuce in children, and $\mathrm{PR}$ receptors were also investigated to rule out the distribution of three hormone receptors in penile tissues of patients without hypospadias were also investigated; an equal distribution in both $A R$ and ER receptors in the prepuce were demonstrated, however PR receptor was not present [22]. In regard to patients with hypospadias, regardless of the degree of hypospadias, positive results of the AR and ER receptors were found, but $P R$ receptors were found negative in all tissues. It is a fact that in children with hypospadias, all specimens from the prepuce and neighborhood of urethral plate and the inner layer of prepuce had either only estrogen or both $\mathrm{ER}$ and $\mathrm{AR}$ receptor expression as in our study. No expression of only AR receptor in any sampled penile tissue was found. In addition, ER and $\mathrm{AR}$ receptors did not have a special side of expression among the prepuce, glans and urethral plate. According of our results, the dominant expression of ER receptors (87.8\%) can be assumed when compared to AR (36.4\%) and $\mathrm{PR}$ receptors $(0 \%)$ in penile tissues of children with hypospadias; these results may be demonstrated the postnatal finding of disrupted estrogen and androgen receptor interaction during the intrauterine development of external genitalia. However, it's hard to speculate that 
the reasons of negative progesterone results as the progesterone is a hormone for pregnancy, the role could be pregnancy related.

This study is a preliminary report consisting of a limited number of patients with distal and middle penile type of hypospadias. This study took our knowledge about the expression and role of sex hormone receptors to a further point as this study have a larger number of patients with a different degree of hypospadias control group. However, the weak side of this study is absent from a real control group and the ER-beta hormone receptor expression with regard to functionality. The dilemna whether "bypospadias development is related to the absence of the androgenic receptor, and/or to the imbalance of the estrogenic/androgenic receptor, or whether receptors are not present because there is no tissue", or "whether receptors are not present because there is no tissue" is partly answered in our recent published corresponding study looking to $A R$ and ER receptors in circumcised patients, where we demonstrated that both $A R$ and ER receptors had been present in all intact prepuce tissues [16]. The effects of ER during the intrauterine development of normal urogenital tract are known $[17,18]$. As this present study emphasized the dominant expression of ER receptors in the penile tissues of children with hypospadias, the theory of disrupted AR and ER receptors interaction and/ or balance could play a role during the development of external genitalia in patients with hypospadias. Some questions as following still have to be answered: If a balance between $E R$ and $A R$ receptors in the development of penile tissues is present, should topical sex hormones be used routinely, especially testosterone before the hypospadias surgery should it be combined with topical ER in a certain percentage? Further studies "if exists" with regard to the possible inhibitory effect of ER in the penile tissues during the intrauterine and/or postnatal development in hypospadias will help to solve guestion about the relation of sex hormone distribution and these hormonal functions in the urogenital tract. Further studies to investigate and demonstrate the exact mechanism of this hormone receptors function/dysfunction leading to certain pathology are still required.

In conclusions, this study showed that " $\mathrm{PR}$ receptor was not present in penile tissues and prepuce, and therefore $\mathrm{PR}$ does not have an active role in the postnatal period, for the urethral plate and/or hypospadias development". There was no manifest correlation of $\mathrm{AR}$ receptor absence with regard to severity of the hypospadias; and there was a marked ER receptors presence in the penile tissues.
Acknowledgements: Authors thank Osman Zeki Pektas, M.D. for giving to us same tissue samples from his patients with hypospadias and Mehmet Elicevik, M.D. for helping to design and write the manuscript.

Conflict of Interest: The authors declare no conflict of interest.

Financial Disclosure: The authors declared that this study has received no financial support.

Authorship Contributions: Concept - RSC; Design - AC, RSC, ME; Supervision - AC, RSC; Materials - AC, SM, OZP; Data collection and /or processing - $\mathrm{HC}, \mathrm{GK}, \mathrm{AC}, \mathrm{SM}$; Analysis and/or interpretation HC, GK; Writing - AC, RSC, ME; Critical review - RSC.

\section{REFERENCES}

1. Sinisi AA, Pasquali D, Notaro A, Bellastella A. Sexual differentiation.J Endocrinol Invest 2003;26:23-8.

2. Warne GL, Kanumakala S. Molecular endocrinology of sex differentiation. Semin Reprod Med 2002;20:169-80. [CrossRef]

3. Rey R, Picard JY. Embryology and endocrinology of genital development. Baillieres Clin Endocrinol Metab 1998;12:17-33. [CrossRef]

4. Kim KS, Liu W, Cunha GR, Russell DW, Huang H, Shapiro E, et al. Expression of the androgen receptor and 5 alpha-reductase type 2 in the developing human fetal penis and urethra. Cell Tissue Res 2002;307:145-53. [CrossRef]

5. Crescioli C, Maggi M, Vannelli GB, Ferruzzi P, Granchi S, Mancina R, et al. Expression of functional estrogen receptors in human fetal male external genitalia. J Clin Endocrinol Metab 2003;88:1815-24. [CrossRef]

6. Tannour-Louet M, Han S, Louet JF, Zhang B, Romero K, Addai J, et al. Increased gene copy number of VAMP7 disrupts human male urogenital development through altered estrogen action. Nat Med 2014;20:715-24. [CrossRef]

7. Mowa CN, Jesmin S, Miyauchi T. The penis: a new target and source of estrogen in male reproduction. Histol Histopathol 2006;21:53-67.

8. Dietrich W, Haitel A, Huber JC, Reiter WJ. Expression of estrogen receptors in human corpus cavernosum and male urethra. J Histochem Cytochem 2004;52:355-60. [CrossRef]

9. Celayir S, Eliçevik M, Tireli G, Dervisoğlu S, Sander S. Expression of estrogen and androgen receptors in children with hypospadias: preliminary report. Arch Androl 2007;53:83-5. [CrossRef]

10. Kim KS, Torres CR Jr, Yucel S, Raimondo K, Cunha GR, Baskin LS. Induction of hypospadias in a murine model by maternal exposure to synthetic estrogens. Environ Res 2004;94:267-75. [CrossRef]

11. Klip H, Verloop J, van Gool JD, Koster ME, Burger CW, van Leeuwen FE; OMEGA Project Group. Hypospadias in sons of women exposed to diethylstilbestrol in utero: a cohort study. Lancet 2002;359:1102-7.

12. Hsu SM, Raine L, Fanger H. Use of avidin-biotin-peroxidase complex $(\mathrm{ABC})$ in immunoperoxidase techniques: a comparison between $\mathrm{ABC}$ and unlabeled antibody (PAP) procedures. J Histochem Cytochem 1981;29:577-80. [CrossRef]

13. Hutson JM, Baskin LS, Risbridger G, Cunha GR. The power and perils of animal models with urogenital anomalies: handle with care. J Pediatr Urol 2014;10:699-705. [CrossRef]

14. Renfree MB, O WS, Short RV, Shaw G. Sexual differentiation of the urogenital system of the fetal and neonatal tammar wallaby, Macropus eugenii. Anat Embryol (Berl) 1996;194:111-34. [CrossRef]

15. Russell AJ, Gilmore DP, Mackay S, Ullmann SL, Baker PJ, Payne AP. The role of androgens in development of the scrotum of the grey short- 
-tailed Brazilian opossum (Monodelphis domestica). Anat Embryol (Berl) 2003;206:381-9. [CrossRef]

16. Fadem BH, Harder JD. Evidence for high levels of androgen in peripheral plasma during postnatal development in a marsupial: the gray short-tailed opossum (Monodelphis domestica). Biol Reprod 1992;46:105-8. [CrossRef]

17. Cunha GR, Risbridger G, Wang H, Place NJ, Grumbach M, Cunha TJ, et al. Development of the external genitalia: perspectives from the spotted hyena (Crocuta crocuta). Differentiation 2014;87:4-22.

18. Vottero A, Minari R, Viani I, Tassi F, Bonatti F, Neri TM, et al. Evidence for epigenetic abnormalities of the androgen receptor gene in foreskin from children with hypospadias. J Clin Endocrinol Metab 2011;96:E1953-62. [CrossRef]
19. Schultheiss D, Badalyan R, Pilatz A, Gabouev AI, Schlote N, Wefer $\mathrm{J}$, et al. Androgen and estrogen receptors in the human corpus cavernosum penis: immunohistochemical and cell culture results. World J Urol 2003;21:320-4. [CrossRef]

20. Enmark E, Gustafsson JA. Oestrogen receptors - an overview. J Intern Med 1999;246:133-8. [CrossRef]

21. Kuiper GG, Enmark E, Pelto-Huikko M, Nilsson S, Gustafsson JA. Cloning of a novel receptor expressed in rat prostate and ovary. Proc Natl Acad Sci U S A 1996;93:5925-30. [CrossRef]

22. Celayir S, Celayir A, Moralıoglu S, Çetiner H, Kır G. Expression of estrogen, progesterone and androgen hormone receptors in the urogenital track of children: Target preputium. Çocuk Cerrahisi Dergisi 2015;29:62-6. [CrossRef] 